\title{
SBs Purchase Determinants in Italian Market: A Survey of Different Retailers' Shoppers
}

\author{
Guido Cristini ${ }^{1}$, Cristina Zerbini ${ }^{1}$ \\ ${ }^{1}$ Department of Economics and Management, University of Parma, Italy \\ Correspondence: Cristina Zerbini, Department of Economics and Management, University of Parma, Italy.
}

Received: April 20, 2017

Accepted: May 23, $2017 \quad$ Online Published: July 4, 2017

doi:10.5539/ibr.v10n8p1

URL: https://doi.org/10.5539/ibr.v10n8p1

\begin{abstract}
Determinants of the growth of store brands (SBs) have been widely investigated in marketing literature. However, with reference to consumer studies, no contributions have focused on comparing strategies developed by grocery retailers to create SB value based on consumer evaluations. The present study aims to fill this knowledge gap by analysing the reasons behind the choice of SBs by consumers who shop at various retailers in Italian market. Data was collected through a computer-assisted telephone interview technique (CATI) based on a structured questionnaire. The final sample was formed by 979 SBs shoppers. The results show that, despite the evidence that socio-demographic profile of the shopper does not vary depending on the retailer attended, the level of importance of SB purchase determinants tend to differ for each retailer: this may reflect the way each distributor has developed its SB products and, therefore, the corresponding strategy adopted. These findings have several implications for retailer policy in positioning SB products.
\end{abstract}

Keywords: store brands, grocery retailers, store brands strategy, purchasing behaviour, socio-demographic profile

\section{Introduction}

Store brands (SBs), also known as private-label brands, have de veloped extensively since they appeared on the retail market. Their growth can be attributed to the increase in retailers' power, which has also simultaneously improved the quality of SB products in relation to meeting consumer needs (Sethuraman, 2006). This expansion in SBs has also been caused by a change in consumer attitudes toward them (Martínez \& Montaner, 2008).

The success achieved by these brands justifies the extensive literature on the topic, which began with a pioneristic study by Myers (1967). More precisely, there are several lines of research in which the theme has been articulated. The first concerns the level of equity reached by SBs (e.g. Ailawadi \& Harlam, 2004) and their degree of development (e.g. Herbert, 2009; Jin \& Gu Suh, 2005). Some researchers (e.g. Herbert, 2009) have shown that SBs' development and management is influenced by four main factors: country, category, customer and consumer (the four "C's"); others have examined the growth of SBs in different store formats (Jin \& Gu Suh, 2005). Another area of research has focused on marketing strategies adopted by distributors. Ailawadi, Neslin and Gedenk (2001), for example, studied the strategies developed to increase SB penetration in different product categories (e.g. Dhar \& Hoch, 1997), while other scholars have focused on price positioning and promotion in relation to the category and the role of manufacturer brands (e.g. Livesey \& Lennon, 1978), or on display space at point of sale (Walsh \& Mitchell, 2010). On the demand side, several studies have investigated the socio-demographic profile of SB shoppers. Specifically, particular attention has been given to level of education (Burger \& Schott, 1972; Murphy, 1978; Cunningham, Hardy, \& Imperia, 1982), age (Cunningham et al., 1982), social class (Murphy, 1978) and price sensitivity (Livesey \& Lennon, 1978). Contextually, SB choice determinants have also been extensively studied, such as price (e.g. Dodds, Monroe, \& Grewald, 1991), qualityprice ratio (e.g. Hoch \& Banerji, 1993; Richardson, Jain, \& Dick, 1996), role of promotions (e.g. Sethuraman \& Mittelstaedt, 1992; Gedenk \& Neslin, 1999) and the strength of customer brand loyalty (e.g. Burton, Lichtestein, Netemeyer, \& Garretson, 1998). Finally, some studies have focused on consumer behaviour according to categories (e.g. Bettman, 1974; DelVecchio, 2001; Metha, 2007). Indeed, SBs have a range of connotations and functions for the final consumer, not only on the basis of general characteristics (in the case of a fast-moving consumer good or a durable product), but also on the basis of the economic, functional and social implications of the purchased product. Certain scholars have focused their attention on consumer behaviour regarding the 
segmentation of supply by distributors in planning and distinguishing different types of SBs. In this context, it has been demonstrated that consumer responses vary according to the different segments (i.e. premium, value, etc.) and functions (e.g. environmentally friendly, organic, free from, etc.) of SB products (e.g. Richardson, Dick, \& Jain, 1994; Davies, 1998; Dhar \& Hoch, 1997).

In light of the high number of extant studies, it is clear that the topic of SBs has been widely addressed and debated. However, none of the research conducted to date has focused on comparisons of consumers across different grocery retailers. In other words, it is currently unclear whether there is a typical buyer of SBs that is equal for all retailers, or if the SB consumer profile differs according to retailer. Furthermore, no studies in the literature to date have investigated the existence of differences in SB product purchase determinants across retailers, given the different positioning strategies adopted by retailers.

This study aims to contribute to the SB literature by increasing knowledge on the consumer profile and on purchasing determinants by analysing the presence of difference among grocery distributors.

Specifically, two main aspects are considered: first, the paper analyses whether the socio-demographic profile of SB shoppers differs among customers of different retailers; second, with reference to the SB distribution strategy, we assess whether different clusters of consumers show common behaviour patterns. In particular, we look at reasons behind the purchase of SBs among customers of different retailers. Some distributors, in fact, offer their customers SB products in different segments, while others offer only standard products. For some retailers, SBs are an important vehicle of communication for core values, which may include aspects such as ethics, safety and investment in social activities. For others, they are simply a cheaper alternative to manufacturer brands.

Besides the theoretical implications, this study also has practical implications for retailers with reference to SB strategies and the consumer relationship. Identifying differences in SB purchase determinants among consumers of different retailers represents relevant information for distribution strategies.

The paper is structured as follows. The next section reviews the literature and develops the research hypotheses. This is followed by an explanation of the methodology used. The subsequent sections detail the results and discussion, highlighting theoretical and managerial implications. Limits of the study and suggestions for further research are examined in the final section.

\section{Literature Review and Hypotheses}

\subsection{Socio-demographic Profile}

As highlighted by Dick, Jain and Richardson (1995) and Fernandez and Martinez (2004), retailers need to know the profile of SB consumers in order to improve the position of their brands in the market. In light of this, several researchers have examined the traits of consumers who purchase SB products, with the first studies published as early as the 1960s (e.g. Frank \& Boyd, 1965; Myers, 1967; Burger \& Schott, 1972; Dick et al., 1995; Burton et al., 1998; Ailawadi et al., 2001; Martìnez \& Montaner, 2008). Over time, several variables have been used to analyse consumer profiles with regard to socio-demographic characteristics. However, contrasting results have been found in the literature.

With reference to the age variable, some authors have affirmed that young people are the main buyers of SB products (Dick et al., 1995; Omar, 1996), while others were not able to identify a specific consumer profile on the basis of age (Richardson et al., 1996; Burton et al., 1998). Similarly, with regard to the level of education, the results reported in the literature vary: according to Omar (1996) and Martìnez and Montaner (2008), people with a lower level of education are more likely to SB products, while according to Richardson et al. (1996) there is no significant relationship between the level of education and the profile of the typical buyer of SBs. Contradictory results have also been observed for the income variable. Although Cunningham et al. (1982) found no link bet ween income and consumer profile, Dick et al. (1995) and Richardson et al. (1996) argued that a significant relationship exists. However, while Dick et al. (1995) stated that consumers who prefer SB products are those with an average income, Richardson et al. (1996) affirmed that SB products are preferred by people with a lower income. The only variable for which consistent results have been found in the literature is household size: SB products are purchased more frequently by larger families (Dick et al., 1995; Omar, 1996; Richardson et al., 1996). Finally, according to Martìnez and Montaner (2008), most socio-demographic characteristics do not seem to be relevant in defining the SB consumer profile.

Given these conflicting results, this paper intends to verify whether there is a common profile among buyers of SB products from different retailers. The research aims to verify the assumption that the socio-demographic profile of the SB product buyer does not differ significantly across the various distributors. Indeed, in a mass market, we 
assume that the SB consumer profile will probably not change, given that the retailers themselves are often interchangeable as channels.

More formally, the following hypothesis is stated:

H1. The socio-demographic characteristics of SB buyers - that is, (a) age, (b) gender, (c) marital status, (d) household size, (e) level of education and (f) professional status - do not vary among Italian grocery retailers.

\subsection{SB Purchase Determinants}

Literature on retailing has long examined consumers' reasons for purchasing SBs. Some studies have shown that consumer decisions to buy SBs are made on the basis of comparison with the manufacturer's brand on the shelves. As described by Kirmani and Wright (1989) and Aaker (1996), the higher value of the manufacturer's brand is the result of heavy investment in innovation and communication over time, which make the brand distinctive. Indeed, the consumer is aware that the producer's investment in the brand is proof of its validity in terms of being higher quality and thus meriting the related financial risk. Thus, consumers who opt for a product that is not part of the manufacturer's brand are aware that they are taking a risk (in terms of negative quality differential) and look for a signal that the potential disadvantage will be lowered or removed (DelVecchio, 2001). The risk can be linked to a potential function disadvantage (intrinsic quality, aesthetic aspects, perceived quality, innovation in terms of use and/or conservation, etc.), which is largely linked to the profile of the SB product category. Some studies have emphasized that the risk is greater when the category is: complex (DelVecchio, 2001), subject to variation over time (Bettman, 1974), or characterized by a low frequency of repurchasing (Narasimhan, Neslin, \& Sen, 1996). Theoretically, each of these aspects makes the consumer more sensitive to a recognized brand that lowers the functional risk.

It is well known that the main advantage that SB products offer to consumers is low price; this has always been the leading reason to buy SBs. However, while the quality of SBs was once considered inferior to that of national brands, consumer opinion about this has changed over time. The results of a study conducted by Verhoef, Nijssen and Sloo (2002) showed an improvement in assessments of the quality of SB products by consumers. Indeed, as the objective quality of SB products has increased, the differential compared to national brands has diminished (Sethuraman \& Gielens, 2014). Price and perceived quality are the major determinants of SB brand selection (e.g. Beneke, Flynn, Greig, \& Mukaiwa, 2013; Erdem, Zhao, \& Valenzuela, 2004; Steenkamp \& Geyskens, 2013; Hoch \& Banerji, 1993).

Alongside the two determinants discussed above, other factors have emerged as relevant in the purchasing choices pertaining to SBs. Bodur, Tofighi and Grohmann (2016), for example, showed the importance that consumers assign to ethical elements related to the brand - that is, product attributes that determine a positive impact on environmental protection, animal welfare, human rights and social issues (Gupta \& Kumar, 2013; Luchs, Naylor, Irwin, \& Raghunathan, 2010; Irwin \& Naylor, 2009). According to the Bodur et al. (2016), SBs benefit from the presence of ethical attributes if they are premium products sold at a higher price, or when the retailer has a good reputation. In relation to ethics, the concept of sustainability is also becoming increasingly important in consumer decisions (Gupta \& Kumar, 2013). Indeed, this has led to demands for sustainable retailers that, in turn, offer sustainable products. The growing consumer attention towards the environment has increased the importance assigned to actions supporting environmental protection. Finally, another aspect that should be considered among SBs purchase determinants is the level of innovation. Although traditionally retailers have been concerned with service innovation, leaving product innovation in the hands of national-brand manufacturers (Doyle \& Bridgewater, 1998; Hardaker, 1998), currently even distributors are investing in product innovation (Conn, 2005). This new strategy has led to the development of a unique and distinctive assortment from each retailer.

In light of the above mentioned literature, the present paper investigates whether the purchase of SBs by Italian consumers depends mainly on cost savings or on other aspects, such as quality, ethics, sustainability or innovation; indeed, the latter, may represent, as highlighted by the literature, the relevant variables in the choice context by consumers. This issue is a traditional area of inquiry in the retailing literature, but in this study the attention is focused on the individual-retailer level, since no studies to date have analysed the subject from this perspective. Indeed, we aim to discover whether the reasons for SB purchase are the same or vary across different retailers, specifically in the Italian market. It is important to discover whether SB products are bought for reasons apart from the price differential with leading brands. If other reasons are identified, this would mean that there is no longer a perception of risk in abandoning manufacturer brands, which would show that certain distributors have succeeded in building value into their SBs.

Therefore, the study analyses the level of importance of individual determinants for each retailer, and assesses 
the existence of differences among Italian distributors. Given the range of strategies pursued by retailers -that differ among them in terms of positioning of the SB as a result of the management of the investments made on the store chain and SBs-, the assumption underlying this analysis is that there are significant differences in the assessment of determinants' importance between customers of various retailers. More formally, the following hypothesis is formulated:

H2. The importance of SB purchase determinants - that is, (a) price, (b) quality, (c) ethics, (d) sustainability and (e) innovation - varies among customers of different Italian grocery retailers.

\section{Methodology}

\subsection{Sample and Procedure}

The data was collected among a panel composed of shopper loyalty card holders of the major retailers operating in the Italian market, and representative of the Italian population. Participants were interviewed indi vidually from October to November 2013. The computer-assisted telephone interview technique (CATI) was used for data collection as it was felt that using telephone interviews would save on cost and time. The interviews were based on a structured questionnaire.

The variables of interest were measured by asking participants to indicate on a scale from 1 to $5(1=$ disagree, $5=$ agree) their level of agreement with statements about the price, quality, ethics, sustainability and level of innovation of SB products. All items used in the questionnaire are shown in Table 1 with the relative reliability indices. Socio-demographic information was also collected during the interview.

Table 1. Items and reliability index

\begin{tabular}{llc}
\hline & & Cronbach's alpha \\
\hline \multirow{2}{*}{ Price } & $\begin{array}{l}\text { There is a good quality-price ratio for SB products. } \\
\text { These products are often on special offer. } \\
\text { There are very good offers on these products. }\end{array}$ & 0.79 \\
\hline \multirow{2}{*}{ Quality } & $\begin{array}{l}\text { I trust the quality of these products. } \\
\text { The products are checked and certified. } \\
\text { These products are made with quality raw materials and ingredients. } \\
\text { I trust these products. }\end{array}$ & 0.85 \\
\hline Ethics & I believe that manufacturers comply with ethical standards. & - \\
\hline Sustainability & $\begin{array}{l}\text { The packaging of these products is environmentally friendly. } \\
\text { The products are environmentally sustainable. }\end{array}$ & 0.84 \\
\hline Innovation & $\begin{array}{l}\text { I often find new SB products. } \\
\text { These products offer new solutions to meet my own and my family's } \\
\text { needs. }\end{array}$ & 0.74 \\
\hline
\end{tabular}

The initial panel was composed of 1631 shoppers. However, since the present paper aimed to analyse the perceptions of SB products by consumers in relation to their favourite retailer, each respondent indicated the retailer they visited most for grocery purchases and if they purchase SB products regularly. In addition, as it was necessary to make a comparison between store chains, we required a balanced number of responses among them, so we selected the six most popular retailers operating in the Italian market. The final sample was formed by 679 SBs shoppers (Table 2). The respondents' profile is shown in Table 3.

Table 2. Number of consumers for store chains

\begin{tabular}{ccc}
\hline Chain Store & Loyal Customers & $\%$ \\
\hline 1 & 122 & 17.97 \\
2 & 143 & 21.06 \\
3 & 120 & 17.67 \\
4 & 87 & 12.81 \\
5 & 128 & 18.85 \\
6 & 79 & 11.64 \\
\hline TOTAL & $\mathbf{6 7 9}$ & $\mathbf{1 0 0}$ \\
\hline
\end{tabular}


Table 3. Characteristics of the sample

\begin{tabular}{|c|c|c|}
\hline & Items & $\%(n=679)$ \\
\hline \multirow{2}{*}{ Gender } & Male & 51.0 \\
\hline & Female & 49.0 \\
\hline \multirow{3}{*}{ Age (years) } & $18-29$ & 17.5 \\
\hline & $30-54$ & 56.3 \\
\hline & Over 55 & 26.2 \\
\hline \multirow{6}{*}{ Level of education } & None or primary school & 0.4 \\
\hline & Lower middle school diploma & 10.2 \\
\hline & Upper school diploma & 54.2 \\
\hline & University degree (three-year first cycle) & 9.9 \\
\hline & University degree (second cycle) & 20.2 \\
\hline & Postgraduate & 5.6 \\
\hline \multirow{6}{*}{ Marital status } & Single & 31.7 \\
\hline & Married & 59.8 \\
\hline & Separated & 3.2 \\
\hline & Divorced & 2.9 \\
\hline & Widowed & 1.3 \\
\hline & Unspecified & 1.0 \\
\hline \multirow{4}{*}{ No. of family members } & 1 & 9.6 \\
\hline & 2 & 29.2 \\
\hline & 3 & 26.8 \\
\hline & 4 or more & 34.5 \\
\hline \multirow{8}{*}{ Professional status } & Open-ended employment contract & 51.3 \\
\hline & Fixed-term employment contract & 10.0 \\
\hline & Seeking first job & 1.2 \\
\hline & Unemployed & 9.3 \\
\hline & Student & 6.0 \\
\hline & Homemaker & 9.1 \\
\hline & Retired & 0.9 \\
\hline & Pensioner & 12.2 \\
\hline
\end{tabular}

\section{Results}

\subsection{Socio-demographic Profile}

In order to test $\mathrm{H} 1$ and analyse the existence of any differences among the socio-demographic profiles of consumers across several retailers, we applied Pearson's chi-square $\left(\chi^{2}\right)$ test (Fisher, 1922; Pearson, 1900) with Monte Carlo simulation.

The first investigated variable was age. The results revealed the absence of significant differences in the age of SB shoppers among the various retailers $\left(\chi^{2}(10)=3.725 ; p>0.05\right)$, thereby supporting H1a. Concurrently, the analysis supported $\mathrm{H1}$ b, as it showed that the shoppers' gender did not differ across retailers $\left(\chi^{2}(5)=10.975\right.$; $\mathrm{p}>0.05)$. Also supported were $\mathrm{H} 1 \mathrm{c}$ and $\mathrm{H} 1 \mathrm{~d}$ : the results did not reveal differences in the marital status $\left(\chi^{2}(25)=29.465 ; p>0.05\right)$ or number of family members $\left(\chi^{2}(15)=16.408 ; p>0.05\right)$ of respondents across different retailers. Finally, as predicted in H1e and H1f, the profile of customers of different retailers did not differ with reference to level of education $\left(\chi^{2}(25)=37.356 ; p>0.05\right)$ or professional status $\left(\chi^{2}(35)=40.338 ; p>0.05\right)$.

In conclusion, the findings reveal that the SB-customer profile did not differ among grocery distributors; therefore, all aspects of $\mathrm{H} 1$ can be accepted. The chi-square values and relative levels of significance are shown in Table 4.

Table 4. Chi-square values and hypotheses results

\begin{tabular}{lccc}
\hline \multicolumn{1}{c}{ Hypotheses } & \multicolumn{1}{c}{ Test } & $\mathrm{p}$-value & Supported/Rejected \\
\hline H1a - Age & $\chi^{2}(10)=10975$ & $\mathrm{p}>0.05$ & Supported \\
H1b - Gender & $\chi^{2}(5)=3.752$ & $\mathrm{p}>0.05$ & Supported \\
H1c - Marital status & $\chi^{2}(25)=29.465$ & $\mathrm{p}>0.05$ & Supported \\
H1d - Number of family members & $\chi^{2}(15)=16.408$ & $\mathrm{p}>0.05$ & Supported \\
H1e - Level of education & $\chi^{2}(25)=37.356$ & $\mathrm{p}>0.05$ & Supported \\
H1f - Professional status & $\chi^{2}(35)=40.338$ & $\mathrm{p}>0.05$ & Supported \\
\hline
\end{tabular}

4.2 SB Purchase Determinants

To verify $\mathrm{H} 2$, a one-way analysis of variance (ANOVA) was run. This made it possible to identify any differences in SB purchase determinants among customers of different retailers (within-group comparisons).

At a descriptive level, all the retailers had predominantly the same rank in terms of the importance of SB purchase determinants (price was always in first place, followed by quality, and subsequently the remaining 
determinants); Table 5 shows the average value of the variables for each chain store. However, as expected in view of the previous literature, statistically interesting differences emerge.

Specifically, the judgement regarding price advantage, although ranked first among SB purchase determinants for all grocery distributors, differed significantly among them $(\mathrm{F}(5,673)=3.532 ; \mathrm{p}<0.05)$, thus supporting H2a. Contextually, a significant difference was also detected with respect to the perceived quality $(\mathrm{F}(5,673)=5.732$; $\mathrm{p}<0.05$ ), despite being positioned in second place for all retailers. This supports $\mathrm{H} 2 \mathrm{~b}$. As we hypothesized in $\mathrm{H} 2 \mathrm{c}$, the importance of the ethic determinant differed within the group of consumers under study $(F(5,673)=6.021$; $\mathrm{p}<0.05$ ). Whit reference to sustainability, as equality of variance was not present, we used the Welch's $\mathrm{F}$ robustness test (Welch, 1951). Even in this case, a significant difference emerged from the analysis ( $\mathrm{F}(5$, 297) $=4.727$; $\mathrm{p}<0.05$ ), supporting $\mathrm{H} 2 \mathrm{~d}$.

Finally, the same results were found with regard to the innovation determinant $(F(5,673)=2.939 ; p<0.05)$, in accordance with $\mathrm{H} 2 \mathrm{e}$ : among consumers of SBs across various retailers, significant differences were found relating to the judgement attributed to the level of innovation.

The ANOVA results and hypotheses results are shown in Table 6.

Table 5. Variable average for each chain store

\begin{tabular}{|c|c|c|c|c|c|}
\hline Store Chain & Price & Perceived quality & Ethics & Sustainability & Innovation \\
\hline 1 & 3.56 & 3.27 & 3.02 & 2.93 & 2.93 \\
\hline 2 & 3.91 & 3.71 & 3.62 & 3.35 & 3.26 \\
\hline 3 & 3.91 & 3.67 & 3.26 & 2.96 & 2.90 \\
\hline 4 & 3.91 & 3.86 & 3.69 & 3.44 & 3.14 \\
\hline 5 & 4.05 & 3.69 & 3.52 & 3.25 & 3.27 \\
\hline 6 & 3.80 & 3.40 & 3.05 & 2.90 & 3.23 \\
\hline \multicolumn{6}{|c|}{ Table 6. ANOVA test and hypotheses results } \\
\hline \multicolumn{2}{|c|}{ Hypotheses } & \multicolumn{2}{|c|}{ Test } & \multicolumn{2}{|r|}{ Supported/Rejected } \\
\hline \multicolumn{2}{|l|}{ H2a-Price } & \multicolumn{2}{|c|}{$\mathrm{F}(5,673)=3.532$} & \multicolumn{2}{|r|}{ Supported } \\
\hline \multicolumn{2}{|c|}{$\mathrm{H} 2 \mathrm{~b}$ - Perceived quality } & \multicolumn{2}{|c|}{$\mathrm{F}(5,673)=5.732$} & \multicolumn{2}{|r|}{ Supported } \\
\hline \multicolumn{2}{|l|}{$\mathrm{H} 2 \mathrm{c}-$ Ethics } & \multicolumn{2}{|c|}{$\mathrm{F}(5,673)=6.021$} & \multicolumn{2}{|r|}{ Supported } \\
\hline \multicolumn{2}{|c|}{$\mathrm{H} 2 \mathrm{~d}-$ Sustainability } & \multicolumn{2}{|c|}{$\mathrm{F}(5,297)=4.727$} & \multicolumn{2}{|r|}{ Supported } \\
\hline \multicolumn{2}{|c|}{$\mathrm{H} 2 \mathrm{e}$ - Innovation } & \multicolumn{2}{|c|}{$F(5,673)=2.939$} & \multicolumn{2}{|r|}{ Supported } \\
\hline
\end{tabular}

\section{Conclusion and Implications}

The results of the study provide important insights for managers of Italian grocery retailers.

First, our results show that the socio-demographic profile of SB purchasers does not explain consumer behaviour. In other words, our analysis of the characteristics considered (gender, age, professional status, level of education, etc.) yields no explanations for behaviour. Although a great deal of literature (Ailawadi et al., 2001; Burton et al., 1998) has identified certain factors as determinants, our findings confirm our hypothesis that socio-demographic factors do not explain loyalty for retailer or for SBs products.

The growing tendency of consumers to be cross-channel, which is occurring in Italy as well as in all commercially advanced countries, could explain our finding regarding the absence of differences in SB consumer profiles among grocery retailers. Indeed, the same shopper is used to frequenting most retailers. This would explain the absence of a differentiated consumer profile for each retailer.

Regarding our second hypothesis, our findings clearly show that shoppers' choice factors differ across retailers. This reflects the way each chain has de veloped its SB products. It is not surprising that the value hierarchy of SB products reflects the varying positions of retailers in terms of shopper perceptions of factors considered important. In some grocery retailers, the determinants for choosing SBs can be considered preconditions (price and quality); in others, there are differential dimensions such as innovation and communication; while in others, SB products are chosen on the basis of distinctive features such as ethical and sustainable nature.

These differences may have two main causes.

First, the retailer could have undertaken actions, in collaboration with copackers, to develop SB products that focus specifically on certain dimensions that characterize the brand; for example, the distributor may have invested in a strategy to increase intrinsic product quality, ethics or environmental sustainability. In other words, the retailer may have genuinely taken actions aimed at strengthening certain SB elements. For these reasons they may have objectively improved the MDD offered.

A second reason could result from the retailer's adoption of a focused and intense communication strategy aimed at highlighting a single attribute of the SB. This strategy operates directly on the basis of perceptions of the 
consumer, who is informed about the main features characterizing the retailer's SB. In recent years, this policy has also been extensively implemented through digital marketing strategies. Therefore, the spread of a more comprehensive information has contributed to increasing shopper trust in MDD.

These findings have two implications for retailers.

The first is that there may be a gap between the objective strategy of SB product positioning at store level and perceptions of loyal customers. Where the gap is large, it reflects problems in the quantity and quality of communications. Distributors' management may be advised to use these observations to re-examine previous processes in light of final consumer involvement, and if necessary draw up new plans for action. In cases where consumer perceptions of SBs are more positive than their perceptions of the retailer itself, it will be important for the chain to examine the reasons behind. It is clearly necessary to avoid a worsening of customer perception and instead identify and build on the determinants of success.

The second implication concerns retailer policy in positioning its SB products, and its aims in upgrading them. Managers need to decide whether products are correctly positioned and whether the factors underlying positioning are identifiable and measurable. For example, if a product is not perceived to be sustainable, management needs to ask whether this is relevant in light of competitors' products, among other factors, and whether the perception needs to be changed and how. This type of policy may have both internal and external implications concerning suppliers and customers on each side. Internally, Italian grocery distributors need to identify the feasibility of making their SBs distinctive in communicating unique values. In other words, they require a consistent marketing strategy, as well as human and financial resources.

Externally, the requirement for sustainability makes it necessary to find and select the best possible copackers. This means that retailers need to develop a system in collaboration with producers for certification of sustainability, supply chain control, and ensuring perceptions of quality. Each individual distributor thus needs to take significant management and strategic action, though this depends on heavy financial investment. In operational terms, our findings show that all copackers involved in the supply of products need to implement changes. For each area of improvement, the degree of favour of the final consumer for each variable needs to be measured. This is because, on the one hand, SB products are increasingly a strategic asset for retailers and, on the other, competitive advantage depends not so much on short-term promotions but on long-term strategy (Sethuraman, 2003; Swoboda, Haelsig, Schramm-Klein, \& Morschett, 2009).

In conclusion, our findings demonstrate that $\mathrm{SB}$ promotion and enhancement policies need to take into account the perceptions and expectations of loyal customers - namely customers who like the retailer and who identify themselves with the values that it expresses.

\section{Limitations and Further Research}

This study contains several weaknesses in relation to its methodology, which provide opportunities for future research.

First, it discusses consumer perception without focusing on details of the different value dimensions of SB products. Future research could focus on a possible objective gap between consumer perception and SB value construction. In other words, it could measure the dimensions of SBs' distinctiveness and value in terms of cost, quality, and safety, and compare this with consumer perceptions. The findings would help retailers to assess whether the different dimensions are perceived by consumers as intended, and whether this is a determinant of SB purchase. This type of research would clearly require collaboration on the part of each retailer to make relevant information available.

A further opportunity for research lies in the analysis of demand and supply for each type of SB product by separate grocery distributors. Indeed, the present paper notes that consumer expectations and perceptions differ across retailers. Each type of segment (i.e. value, standard, and premium) is, in fact, positioned differently in the range; thus, the values expressed by each brand vary accordingly. The SB stretching carried out by different retailers can be successful where brand-building strategies are consistent and communicated accurately to the target market segment. Currently, in Italy, the expectation is that SBs will continue to grow in various segments, and analysis and measurement of these dimensions could be very relevant and useful for interpreting the competitive advantage held by each retailer.

\section{References}

Aaker, D. A. (1996). Building Strong Brands. New York: The Free Press.

Ailawadi, K. L., \& Harlam, B. (2004). An empirical analysis of the determinants of retail margins: the role of 
store-brand share. The Journal of Marketing, 68(1), 147-165.

http://dx.doi.org/10.1509/jmkg.68.1.147.24027

Ailawadi, K. L., Neslin, S. A., \& Gedenk, K. (2001). Pursuing the value-conscious consumer: Store brands versus national brand promotions. Journal of Marketing, 65(1), 71-89.

http://dx.doi.org/10.1509/jmkg.65.1.71.18132

Beneke, J., Flynn, R., Greig, T., \& Mukaiwa, M. (2013). The influence of perceived product quality, relative price and risk on customer value and willingness to buy: A study of private label merchandise. Journal of Product \& Brand Management, 22(3), 218-228. http://dx.doi.org/10.1108/JPBM-02-2013-0262

Bettman, J. R. (1974). Relationship of information-processing attitude structures to private brand purchasing behavior. Journal of Applied Psychology, 59(1), 79-83. http://dx.doi.org/10.1037/h0035817

Bodur, H. O., Tofighi, M., \& Grohmann, B. (2016). When should private label brands endorse ethical attributes? Journal of Retailing, 92(2), 204-217. http://dx.doi.org/10.1016/j.jretai.2015.11.001

Burger, P. C., \& Schott, B. (1972). Can private brand buyers be identified? Journal of Marketing Research, 9(2), 219-222.

Burton, S., Lichtestein, D. R., Netemeyer, R. G., \& Garretson, J. A. (1998). A scale for measuring attitude toward PL products and an examination of its psychological and behavioral correlates. Journal of the Academy of Marketing Science, 26(4), 293-306. http://dx.doi.org/10.1177/0092070398264003

Conn, C. (2005). Innovation in private - label branding. Design Management Review, 16(2), 55-62. https://doi.org/10.1111/j.1948-7169.2005.tb00194.x

Cunningham, I. C. M., Hardy, A. P., \& Imperia, G. (1982). Generic brands versus national brands and store brands - A comparison of consumers preferences and perceptions. Journal of Advertising Research, 22(5), 25-32.

Davies, G. (1998). Retail brands and the theft of identity. International Journal of Retail \& Distribution Management, 26(4), 140-146. http://dx.doi.org/10.1108/09590559810214903

DelVecchio, D. (2001). Consumer perception of private label quality: the role of product category characteristics and consumer use of heuristics. Journal of Retailing and Consumer Services, 8(5), 239-249. http://doi.org/10.1016/S0969-6989(00)00030-8

Dhar, S. K., \& Hoch, S. J. (1997). Why store brand penetration varies by retailer. Marketing Science, 16(3), 208-227. https://doi.org/10.1287/mksc.16.3.208

Dick, A., Jain, A., \& Richardson, P. (1995). Correlates of store brand proneness: Some empirical observations. Journal of Product \& Brand Management, 4(4), 15-22. http://dx.doi.org/10.1287/mksc.16.3.208

Dodds, W. B., Monroe, K. B., \& Grewald, D. (1991). Effect of price, brand, and store information on buyers' product evaluations. Journal of Marketing Research, 28, 307-318. http://dx.doi.org/10.2307/3172866

Doyle, P., \& Bridgewater, S. (1998). Marketing and innovation. Innovation in Marketing, 1-16.

Erdem, T., Zhao, Y., \& Valenzuela, A. (2004). Performance of store brands: Across-country analysis of consumer store-brand preferences, perceptions, and risk. Journal of Marketing Research, 41(1), 86-100. http://dx.doi.org/10.1509/jmkr.41.1.86.25087

Fernández, N. Á., \& Martínez, C. E. (2004). Las marcas de distribuidor y el consumidor español. Distribución y consume, 77, 12-25.

Fisher, R. A. (1922). On the interpretation of chi square from contingency tables, and the calculation of P. Journal of the Royal Statistical Society, 85, 87-94. https://doi.org/10.2307/2340521

Frank, R. E., \& Boyd Jr, H. W. (1965). Are private-brand-prone grocery customers really different? Journal of Advertising Research, 5(4), 27-35. https://doi.org/10.1016/S0022-4359(99)00018-4

Gedenk, K., \& Neslin, S. A. (1999). The role of retail promotion in determining future brand loyalty: Its effect on purchase event feedback. Journal of Retailing, 75(4), 433-459. http://doi.org/10.1016/S0022-4359(99)00018-4

Gupta, S., \& Kumar, V. (2013). Sustainability as corporate culture of a brand for superior performance. Journal of World Business, 48(3), 311-320. http://doi.org/10.1016/j.jwb.2012.07.015

Hardaker, G. (1998). An integrated approach towards product innovation in international manufacturing 
organisations. European Journal of Innovation Management, 1(2), 67-73. http://dx.doi.org/10.1108/14601069810217248

Herbert, R. (2009). PLs - What drives them forward? In: A. Ezrachi \& U. Bernitz (eds.) PLs, Brands and Competition Policy. Oxford: University Press, 3-20.

Hoch, S. J., \& Banerji, S. (1993). When do private labels succeed? Sloan Management Review, 34(4), 57-67.

Irwin, J. R., \& Naylor, R. W. (2009). Ethical decisions and response mode compatibility: Weighting of ethical attributes in consideration sets formed by excluding versus including product alternatives. Journal of Marketing Research, 46(2), 234-246. http://dx.doi.org/10.1509/jmkr.46.2.234

Jin, B., \& Gu Suh, Y. (2005). Integrating effect of consumer perception factors in predicting private brand purchase in a Korean discount store context. Journal of Consumer Marketing, 22(2), 62-71. http://dx.doi.org/10.1108/07363760510589226

Kirmani, A., \& Wright, P. (1989). Money talks: Perceived advertising expense and expected product quality. Journal of Consumer Research, 16, 344-353. http://dx.doi.org/10.1086/209220

Livesey, F., \& Lennon, P. (1978). Factors affecting consumers' choice between manufacturer brands and retailer own labels. European Journal of Marketing, 12(2), 158-170. http://dx.doi.org/10.1108/EUM0000000004965

Luchs, M. G., Naylor, R. W., Irwin, J. R., \& Raghunathan, R. (2010). The sustainability liability: Potential negative effects of ethicality on product preference. Journal of Marketing, 74(5), 18-31. http://dx.doi.org/10.1509/jmkg.74.5.18

Martìnez, E., \& Montaner, T. (2008). Characterisation of Spanish store brand consumers. International Journal of Retail \& Distribution Management, 36(6), 447-493. http://dx.doi.org/10.1108/09590550810873947

Metha, N. (2007). Investigating consumers' purchase incidence and brand choice decisions across multiple product categories: A theoretical and empirical analysis. Marketing Science, 26(2), 196-217. http://dx.doi.org/10.1287/mksc.1060.0214

Murphy, P. E. (1978). The effect of social-class on brand and price consciousness for supermarket products. Journal of Retailing, 54(2), 33-42.

Myers, J. G. (1967). Determinants of private label attitude. Journal of Marketing Research, 4, 73-81. https://doi.org/10.2307/3150168

Narasimhan, C., Neslin, S. A., \& Sen, S. K. (1996). Promotional elasticities and category characteristics. The Journal of Marketing, 60, 17-30. https://doi.org/10.2307/1251928

Omar, O. E. (1996). Grocery purchase behaviour for national and own-label brands. Service Industries Journal, 16(1), 58-66. http://dx.doi.org/10.1080/02642069600000006

Pearson, K. (1900). On the criterion that a given system of deviations from the probable in the case of a correlated system of variables is such that it can be reasonably supposed to have arisen from random sampling. Philosophical Magazine, 50(5), 157-175. http://dx.doi.org/10.1080/14786440009463897

Richardson, P. S., Dick A. S., \& Jain A. K. (1994). Extrinsic and intrinsic cue effects on perceptions of store brand quality. The Journal of Marketing, 58: 28-36. http://dx.doi.org/10.2307/1251914

Richardson, P. S., Jain, A. K., \& Dick, A. (1996). Household store brand proneness: A framework. Journal of Retailing, 72(2), 159-185. https://doi.org/10.1016/S0022-4359(96)90012-3

Sethuraman, R. (2003). Measuring national brands' equity over store brands. Review of Marketing Science, 1(2), 1-26. https://doi.org/10.2202/1546-5616.1000

Sethuraman, R. (2006). Private-Label Marketing Strategies in Packaged Goods: Management Beliefs and Research Insights. Working Paper Series. Cambridge, MA: Marketing Science Institute.

Sethuraman, R., \& Gielens, K. (2014). Determinants of store brand share. Journal of Retailing, 90(2), 141-153. http://doi.org/10.1016/j.jretai.2014.04.002

Sethuraman, R., \& Mittelstaedt, J. (1992). Coupons and private labels: A cross-category analysis of grocery products. Psychology \& Marketing, 9(6), 487-500. http://doi.org/10.1002/mar.4220090606

Steenkamp, J. B. E., \& Geyskens, I. (2013). Manufacturer and retailer strategies to impact store brand share: Global integration, local adaptation, and worldwide learning. Marketing Science, 33(1), 6-26. 
http://dx.doi.org/10.1287/mksc.2013.0801

Swoboda, B., Haelsig, F., Schramm-Klein, H., \& Morschett, D. (2009). Moderating role of involvement in building a retail brand. International Journal of Retail \& Distribution Management, 37(11), 952-974. http://dx.doi.org/10.1108/09590550910999370

Verhoef, P. C., Nijssen, E. J., \& Sloot, L. M. (2002). Strategic reactions of national brand manufacturers towards private labels: An empirical study in the Netherlands. European Journal of Marketing, 36(11/12), 1309-1326. http://dx.doi.org/10.1108/03090560210445191

Walsh, G., \& Mitchell, V. W. (2010). Consumers' intention to buy private label brands revisited. Journal of General Management, 35(3), 3-24. http://dx.doi.org/10.1177/030630701003500302

Welch, B. L. (1951). On the comparison of several mean values: An alternative approach. Biometrika, 38, 330-336. https://doi.org/10.1093/biomet/38.3-4.330

\section{Copyrights}

Copyright for this article is retained by the author(s), with first publication rights granted to the journal.

This is an open-access article distributed under the terms and conditions of the Creative Commons Attribution license (http://creativecommons.org/licenses/by/4.0/). 